\title{
Jerry Mojalefa
}

\section{Querying the claim of the user-friendliness of the New Sepedi Dictionary}

\section{A B S T R A C T The New Sepedi Dictionary is a concise translating bilingual dictionary. Even though}

the compilers claim that this dictionary is very user-friendly, this can be queried. Accordingly, the main aim of this article is to test the usefulness of this lexicographic compilation. The discussion is restricted to the English-Sepedi part as Sepedi is the target language. A study of the dictionary articles, spelling, unnecessary loanwords, corresponding words, coinages, hyphenated words, repetition of words and inconsistencies display the deficiencies in this dictionary. As a result, it is recommended that the dictionary should be duly revisited and revised.

Keywords: inconsistencies, target language, source language, spelling, orthography, loanwords, corresponding words, coinages, hyphenated words, repetition of words

\section{Introduction}

The New Sepedi Dictionary, published in 1996, can be classified as a pocket-size bilingual translating dictionary. On the back cover of the dictionary, the compilers, Prinsloo and Sathekge, claim that it is the first dictionary in Sepedi (cf. The Constitution of the Republic of South Africa, 1996: 4) based on an actual body of writings, also stressing the user-friendliness of the dictionary:

This is the first dictionary compiled for Sepedi (Northern Sotho) on the basis of frequency of use of Sepedi words. The user will find this dictionary very user-friendly. Entries are short and easy to comprehend. It is also the first dictionary in which the gal sa/se convention is used to assist inexperienced users.

In the foreword, the compilers take the issue of user-friendliness further by stating:

The Sepedi Dictionary is a restricted pocket-size bilingual (Sepedi-English/EnglishSepedi) dictionary. It is very user-friendly. All words can be directly looked up and no 
knowledge of grammatical rules is presupposed. With one exception (explained on the next page), standard dictionary conventions are used.

Strictly speaking, the above argument is based on the purpose or purposes the compilers intend to fulfil. A survey of linguistic literature related to lexicography indicates, according to Al-Kasimi (1983:18), that linguists recommend different types of bilingual dictionaries and furthermore suggest different solutions to the same problem depending on the purpose of the dictionary.

Martin (1967:153) sounds a note of warning by categorically stating that anybody intending to compile a dictionary will have to make a compromise, useful for some purposes and frustrating for others:

You want to make a dictionary that will be concise but exhaustive; exact but not exacting; linguistically adequate for BOTH languages, yet uncluttered with trivial details. Sooner or later you have to concentrate on certain goals and forget others.

Haas (1967:47) adds:

What is even more deplorable ... is the fact that often the compilers are not aware of the problems involved. Thinking that they are preparing a dictionary for speakers of both languages, they may easily end up producing a dictionary which is not as useful as it should be to speakers of either language.

Accordingly, Al-Kasimi, Martin and Haas raise serious concerns regarding the compilation of a bilingual dictionary. These suggest that even though, as the compilers claim, the New Sepedi Dictionary has been designed for user-friendliness, according to the latest accepted standard dictionary conventions, there might still be controversies manifested therein. As a result, the main purpose of this article is to test the genuineness of the claim of Prinsloo and Sathekge with regard to the user-friendliness of the dictionary. Furthermore, the aim is not to focus the discussion on the Sepedi-English section but to restrict the examination to the English-Sepedi section, where Sepedi is the target language.

As the objective is not to discuss the frequency of the Sepedi words in the New Sepedi Dictionary, the validity of the compilers' claim of user-friendliness will therefore be examined by looking at (a) dictionary articles, (b) spelling, (c) unnecessary loanwords, (d) corresponding words, (e) coinage of words, (f) hyphenated words, (g) repetition of words and (h) inconsistencies.

Accordingly, an explanation of the above-mentioned concepts will be of significance in the discussion.

\section{Dictionary articles}

Smit (2002:302) mentions that Wiegand in his article 'Was ist eigentlich ein Lemma? Ein Beitrag zur Theorie der lexikographischen Sprachbeschreibung' strongly shows his preference for certain expressions, such as 'dictionary article' instead of 'dictionary entry'. In this article, although the terms may often be used interchangeably, dictionary articles instead of dictionary entries are employed.

Malkiel (1967) classifies dictionaries using three criteria, namely range, perspective and presentation. With regard specifically to range, dictionaries are divided by density of entries, number of languages involved and extent of concentration on lexical data. 
Smit (2002:302) emphasises that Wiegand in his article, 'Wörterbuchartikel als Text' clearly states that different types of dictionaries indicate different article structures and different degrees of standardisation. She takes this issue further by stating that Wiegand believes that dictionary articles consist of partial texts which he calls 'data types'.

The breadth of coverage may be measured by the density of entries, i.e. how much of the total lexicon of the language is covered, and also by the depth of coverage, i.e. how many meanings are listed under each entry. However, the discussion will be restricted to the density of entries. The following tables give an account of how the included articles are divided among the letters of the alphabet.

A

\begin{tabular}{|c|c|}
\hline Column 1 & Column 2 \\
\hline Page 1: 35 & Page 1: 34 \\
\hline Page 2: 39 & Page 2: 40 \\
\hline Page 3: 41 & Page 3: 39 \\
\hline Page 4: 38 & Page 4: 39 \\
\hline Page 5: 39 & Page 5: 42 \\
\hline Page 6: 39 & Page 6: 38 \\
\hline Page 7: 1 & Page 7: 1 \\
\hline Total number of entries under A: 465 \\
\hline
\end{tabular}

C

\begin{tabular}{|c|c|}
\hline Column 1 & Column 2 \\
\hline Page 11: 39 & Page 11: 39 \\
\hline Page 12: 38 & Page 12: 45 \\
\hline Page 13: 44 & Page 13: 41 \\
\hline Page 14: 39 & Page 14: 36 \\
\hline Page 15: 44 & Page 15: 43 \\
\hline Page 16: 17 & Page 16: 17 \\
\hline \multicolumn{2}{|c|}{ Total number of entries under C: 442} \\
\hline
\end{tabular}

$\mathbf{E}$

\begin{tabular}{|c|c|}
\hline Column $\mathbf{1}$ & Column $\mathbf{2}$ \\
\hline Page 20: 30 & Page 20:32 \\
\hline Page 21: 41 & Page 21: 38 \\
\hline Page 22: 29 & Page 22: 31 \\
\hline \multicolumn{2}{|c|}{ Total number of entries under E: 201} \\
\hline
\end{tabular}

B

\begin{tabular}{|c|c|}
\hline Column 1 & Column 2 \\
\hline Page 7: 38 & Page 7: 37 \\
\hline Page 8: 44 & Page 8: 41 \\
\hline Page 9: 43 & Page 9: 42 \\
\hline Page 10: 40 & Page 10: 44 \\
\hline \multicolumn{2}{|c|}{ Total number of entries under B: 329 } \\
\hline
\end{tabular}

D

\begin{tabular}{|c|c|}
\hline Column 1 & Column $\mathbf{2}$ \\
\hline Page 16: 22 & Page 16: 20 \\
\hline Page 17: 40 & Page 17:37 \\
\hline Page 18: 43 & Page 18: 37 \\
\hline Page 19: 36 & Page 19: 41 \\
\hline Page 20: 4 & Page 20:3 \\
\hline \multicolumn{2}{|c|}{ Total number of entries under D: 283} \\
\hline
\end{tabular}

\begin{tabular}{|l|c|}
\multicolumn{1}{|}{ F } \\
\hline Column 1 & Column 2 \\
\hline Page 22: 2 & Page 22: 2 \\
\hline Page 23: 41 & Page 23: 42 \\
\hline Page 24: 41 & Page 24: 42 \\
\hline Page 25: 34 & Page 25: 28 \\
\hline \multicolumn{2}{|c|}{ Total number of entries under F: 232 } \\
\hline
\end{tabular}


G

\begin{tabular}{|c|c|}
\hline Column $\mathbf{1}$ & Column $\mathbf{2}$ \\
\hline Page 25: 6 & Page 25: 4 \\
\hline Page 26: 39 & Page 26: 41 \\
\hline Page 27: 33 & Page 27: 29 \\
\hline \multicolumn{2}{|c|}{ Total number of entries under G: 152} \\
\hline
\end{tabular}

\section{H}

\begin{tabular}{|c|c|}
\hline Column 1 & Column 2 \\
\hline Page 27: 2 & Page 27: 3 \\
\hline Page 28: 36 & Page 28: 40 \\
\hline Page 29: 42 & Page 29: 39 \\
\hline Page 30: 18 & Page 30 \\
\hline \multicolumn{2}{|c|}{ Total number of entries under H: 198} \\
\hline
\end{tabular}

$\mathbf{J}$

\begin{tabular}{|c|c|}
\hline Column 1 & Column 2 \\
\hline Page 32: 4 & Page 32: 4 \\
\hline Page 33: 11 & Page 33: 15 \\
\hline \multicolumn{2}{|c|}{ Total number of entries under J: 34} \\
\hline
\end{tabular}

L

\begin{tabular}{|c|c|}
\hline Column 1 & Column 2 \\
\hline Page 34: 38 & Page 34: 38 \\
\hline Page 35: 42 & Page 35: 39 \\
\hline Page 36: 4 & Page 36: 4 \\
\hline \multicolumn{2}{|c|}{ Total number of entries under L: 165} \\
\hline
\end{tabular}

\begin{tabular}{|l|c|}
\multicolumn{2}{|c|}{} \\
\hline Column 1 & Column 2 \\
\hline Page 38: 6 & Page 38: 5 \\
\hline Page 39: 38 & Page 39: 32 \\
\hline \multicolumn{2}{|c|}{ Total number of entries under N: 81 } \\
\hline
\end{tabular}

\begin{tabular}{|c|c|}
\multicolumn{2}{c}{ P } \\
\hline Column 1 & Column $\mathbf{2}$ \\
\hline Page 41: 20 & Page 41: 19 \\
\hline Page 42: 40 & Page 42: 39 \\
\hline Page 43: 35 & Page 43: 36 \\
\hline Page 44: 35 & Page 44: 38 \\
\hline Page 45: 36 & Page 45: 34 \\
\hline Page 46: 19 & Page 46: 18 \\
\hline \multicolumn{2}{|c|}{ Total number of entries under P: 369 } \\
\hline
\end{tabular}


Q

\begin{tabular}{|l|c|}
\hline Column $\mathbf{1}$ & Column $\mathbf{2}$ \\
\hline Page 46: 12 & Page 46: 11 \\
\hline \multicolumn{2}{|c|}{ Total number of entries under Q: 23} \\
\hline
\end{tabular}

S

\begin{tabular}{|c|c|}
\hline Column 1 & Column 2 \\
\hline Page 50:32 & Page 50: 31 \\
\hline Page 51:38 & Page 51: 39 \\
\hline Page 52: 39 & Page 52: 38 \\
\hline Page 53: 40 & Page 53: 39 \\
\hline Page 54: 38 & Page 54: 41 \\
\hline Page 55: 36 & Page 55: 36 \\
\hline Page 56: 41 & Page 56: 34 \\
\hline Page 57: 12 & Page 57: 11 \\
\hline Total number of entries under S: 545 \\
\hline
\end{tabular}

$\mathbf{U}$

\begin{tabular}{|c|c|}
\hline Column 1 & Column 2 \\
\hline Page 60: 12 & Page 60: 11 \\
\hline Page 61: 32 & Page 61: 38 \\
\hline Page 62: 3 & Page 62: 4 \\
\hline \multicolumn{2}{|c|}{ Total number of entries under U: 100} \\
\hline
\end{tabular}

\begin{tabular}{|c|c|}
\hline Wolumn 1 & Column 2 \\
\hline Page 63: 35 & Page 63: 36 \\
\hline Page 64: 35 & Page 64: 34 \\
\hline Page 65: 10 & Page 65: 11 \\
\hline Total number of entries under W: 161 \\
\hline
\end{tabular}

\begin{tabular}{|c|c|}
\hline Column 1 & Column 2 \\
\hline Page 65: 2 & Page 65: 2 \\
\hline \multicolumn{2}{|c|}{ Total number of entries under $Z$ : 4} \\
\hline
\end{tabular}

\begin{tabular}{|c|c|}
\hline \multicolumn{1}{|c}{ R } \\
\hline Column 1 & Column 2 \\
\hline Page 47: 36 & Page 47: 30 \\
\hline Page 48: 42 & Page 48: 38 \\
\hline Page 49: 38 & Page 49: 36 \\
\hline Page 50: 3 & Page 50: 1 \\
\hline Total number of entries under R: 224 \\
\hline
\end{tabular}

\begin{tabular}{|c|c|}
\hline \multicolumn{1}{|c}{ T } \\
\hline Column 1 & Column 2 \\
\hline Page 57: 20 & Page 57: 20 \\
\hline Page 58: 36 & Page 58: 37 \\
\hline Page 59: 36 & Page 59: 38 \\
\hline Page 60: 20 & Page 60: 21 \\
\hline \multicolumn{2}{|c|}{ Total number of entries under T: 228} \\
\hline
\end{tabular}

\begin{tabular}{|c|c|}
\hline Column 1 & Column 2 \\
\hline Page 62: 28 & Page 62: 29 \\
\hline \multicolumn{2}{|c|}{ Total number of entries under V: 57} \\
\hline
\end{tabular}

\begin{tabular}{|c|c|}
\hline \multicolumn{2}{|c}{ Y } \\
\hline Column 1 & Column 2 \\
\hline Page 65: 7 & Page 65: 8 \\
\hline \multicolumn{2}{|c|}{ Total number of entries under Y: 15} \\
\hline
\end{tabular}


Admittedly, when a bilingual dictionary is compiled, the number of articles in such a dictionary must be considered, because the lexicographer is restricted by the size of the dictionary. However, this article wants to raise a concern in this regard.

A close investigation of the above figures indicates that the concentration of articles under the different letters is as follows: (a) those between 300 and 550 are under A, B, C, S and P; (b) those between 200 and 299 are under D, E, F, R and T; (c) those between 100 and 199 are placed in articles G, H, I, J, L, M and W; (d) those between 0 and 99 are under K, N, O, Q, U, V, Y and Z, and (e) none are under $\mathrm{X}$.

It should be acknowledged and accepted that the letter X in Sepedi may not have the same number of articles as, for example, the letter M. However, the letter X should be assigned a few core articles rather than none. There are also some deficiencies with regard to the number of articles under other letters such as K (49 articles), Q (23 articles), Y (15 articles) and Z (only 4 articles) in comparison with letters A (465 articles), C (442 articles) and S (545 articles).

A close scrutiny reveals that when the range of coverage is measured against the number of entries (i.e. the equal number of entries per letter of the alphabet) a discrepancy can be observed. Even though the focus was not to highlight depth of coverage of articles in this dictionary, this is also proved to be a problem area.

\section{Spelling}

Mountford (2003:x) says spelling is 'analysis into morphemes and symbols that yield insight'. Wolff (1954) mentions that good orthography has four broad features: accuracy, economy, consistency and similarity. Regarding accuracy and economy Bamgbose (1965:1) argues that 'a good orthography ... should represent all the significant sounds in the language'. He further states that consistency relates to the use of 'only one symbol for each significant sound'. Liberman (1980:51) says that 'the concept of spelling covers both graphemics and orthography'. He defines graphemics as 'a field covering all the means that a language has to render a complex of sounds (phonemes) in writing while he describes orthography as 'a set of rules stating which of the graphemically admissible variants are correct in each individual case'.

Pinsent (1989:13) stresses the importance of correct spelling:

Correct spelling is important in the same way, as clear speech is necessary for communication. If a reader has to puzzle over the words, attention will be diverted from the content and the writer's message may well be blurred.

Spelling is another problem area in the New Sepedi Dictionary. The following mistakes were recorded:

$\begin{array}{llll}\text { incorrect } & \text { correct } & \text { incorrect } & \text { correct } \\ \text { alfabeta } & \text { alfabete } & \text { botsibi } & \text { botsebi } \\ \text { Aporele } & \text { Aprele } & \text { Diabolo } & \text { diabolo } \\ \text { atemosfere } & \text { atmosfere } & \text { difeteria } & \text { difteria } \\ \text { balapa } & \text { balapa } & \text { dihala } & \text { dialal-e } \\ \text { baswa } & \text { bafsa } & \text { diromelantle } & \text { diromelwantle } \\ \text { bitsa } & \text { bitša } & \text { epsomosolete } & \text { epsomsolte } \\ \text { bonišetša } & \text { bonegela } & \text { gonabjale } & \text { gonabjale } \\ \text { bontsha } & \text { bontšha } & \text { hlompho } & \text { tlhompho } \\ \text { boswa } & \text { bofsa } & \text { Janeware } & \text { Janaware }\end{array}$




$\begin{array}{llll}\text { incorrect } & \text { correct } & \text { incorrect } & \text { correct } \\ \text { kabinete } & \text { kapinete } & \text { perompeta } & \text { porompeta } \\ \text { kapotene } & \text { kaptene } & \text { polasitiki } & \text { plastiki } \\ \text { kwišiša } & \text { kwešiša } & \text { posotere } & \text { posotara } \\ \text { LaMorena } & \text { Lamorena } & \text { radeisi } & \text { radiši } \\ \text { lanngele } & \text { lanngele } & \text { reise } & \text { reisi } \\ \text { laSetšhaba } & \text { lasetšhaba } & \text { resene } & \text { rešene } \\ \text { lebotlolo } & \text { lepotlelo } & \text { samengwaga } & \text { samengwaga } \\ \text { lehwatata } & \text { legwatata } & \text { sanywaga } & \text { sanywaga } \\ \text { lekoko } & \text { lekokoko } & \text { Sathane } & \text { sathane } \\ \text { leratadimo } & \text { leratadima } & \text { sefoko } & \text { sefoka } \\ \text { letšolobolo } & \text { letsolobolo } & \text { sentserentsere } & \text { setsentsere } \\ \text { magistrata } & \text { masetrata } & \text { serowa } & \text { seroa } \\ \text { magwagwa } & \text { makgwakgwa } & \text { setarata } & \text { setrata } \\ \text { maseterata } & \text { masetrata } & \text { tekisi } & \text { taxi } \\ \text { mokgabo } & \text { bokgabo } & \text { temokrasi } & \text { demokrasi } \\ \text { morwakgoši } & \text { morwa'kgoši } & \text { teraeka } & \text { tereka } \\ \text { mošimane } & \text { mošemane } & \text { thekisi } & \text { taxi } \\ \text { motšhotšhiši } & \text { motšhotšhisi } & \text { tswa } & \text { tšwa } \\ \text { nagatlase } & \text { nagatlase } & \text { tšwirinya } & \text { tswirinya } \\ \text { ntsetlwana } & \text { ntshetlwana } & \text { wisa } & \text { wiša } \\ \text { pakteria } & \text { bakteria } & & \end{array}$

So far, Northern Sotho Terminology and Orthography No. 4 of 1988 is the only important canon on which written Sepedi is based. Accordingly, it is a decisive document containing the official spelling rules of Standard Sepedi, which has been compiled by the former Sepedi Language Board and is still accepted as an authentic orthographic and spelling document in Sepedi. The compilers of the New Sepedi Dictionary ignored some spelling rules prescribed by Sepedi orthography because almost all the words misspelled in it have been discussed and correctly spelled in Northern Sotho Terminology and Orthography No 4 of 1988 except for a few instances where this publication causes confusion of spelling of words such as pakteria for bakteria, and temokrasi for demokrasi. The compilers should have effectively clarified this spelling problem in their compilation.

\section{Unnecessary loanwords}

Kaye and Nykiel (1979:72) state that 'loan words are borrowed as they appear in the source language unless there is some reason to modify them'. Hence Picard and Nicol (1982:4) assume that if the borrowing language (BL) and the source language (SL) possess a certain identical segment, the presence of this segment in some identical environments in the two languages constitutes a case where no motive for modification exists. They conclude by indicating that:

The study of loan phonology can be viewed as an attempt to deal with the adaptation strategies involved in the two following types of borrowing situations:

(1) SEGMENT X in the SL does not exist in the BL;

(2) SEGMENT X in the SL has an identical counterpart in the BL:

(a) in the same environment;

(b) in a different type of environment.

The following list shows to what degree the compilers have included unnecessary loanwords in the New Sepedi Dictionary in comparison with, for example, Kriel's dictionaries: 


\begin{tabular}{|c|c|c|c|}
\hline beef & $>$ & pifi for kgomobolekana/namakgomo & \\
\hline champion & $>$ & phinere for nkgwete & not lemmatised (Kriel) \\
\hline conceive & $>$ & ingwa for ima/dušalgampa & not lemmatised (Kriel) \\
\hline decoration & $>$ & mokgabo for kgabišo & Tswana (Kriel) \\
\hline fist & $>$ & feisi for letswele & Afrikaans/English (Kriel) \\
\hline gambol & $>$ & kgana for tlolaka & Tswana (to drive) (Kriel) \\
\hline fail & $>$ & feila for palelwa/šitwa & English \\
\hline jeopardise & $>$ & kotsifala for tsenya kotsing & not lemmatised \\
\hline key & $>$ & khii for sekgonyo & English (Kriel) \\
\hline let a house & $>$ & thwala ngwako for hirišaladimiša & not lemmatised \\
\hline library & $>$ & laebrari for bokgobapuku & English (Kriel) \\
\hline load & $>$ & laiša for nametša/rweša & Afrikaans \\
\hline lunatic & $>$ & lehlanya for segaswi/legafa & Nguni (Kriel) \\
\hline lunatic & $>$ & sehlanya & not lemmatised \\
\hline maiden & $>$ & morwetsana for kgarebe/mosetsana & Sesotho (Kriel) \\
\hline mammal & $>$ & mmamala for seamuši/senyantšhi & English (Kriel) \\
\hline measure & $>$ & meta for lekanyetšalela & English \\
\hline mine & $>$ & maene for moepo & English (Kriel) \\
\hline neat & $>$ & makgethe for hlweka/kgahliša & Sesotho \\
\hline pack & $>$ & paka for hlopha/beakanya & English (Kriel) \\
\hline participate & $>$ & tšea karolo for kgatha tema & English/Afrikaans \\
\hline plaintiff & $>$ & motlalei for molli/mmelaedi & Afrikaans \\
\hline pretend & $>$ & ikgakanya for ikgakantšha & not lemmatised \\
\hline pretext & $>$ & boikgakanyo for boiketšišo & not lemmatised (Kriel) \\
\hline public & $>$ & papliki for batho/molaleng & English/Afrikaans (Kriel) \\
\hline rape & $>$ & betelela for kata & Sesotho (Kriel) \\
\hline sediment & $>$ & maitsheko for seretse/leraga & Tswana (Kriel) \\
\hline shawl & $>$ & tšalana for tšajana & not lemmatised \\
\hline spittle & $>$ & mathe for mare & Tswana \\
\hline supreme court & $>$ & kgotlakgolo for kgorotshekokgolo & Tswana (Kriel) \\
\hline supreme court & $>$ & suprimikhoto for kgorotshekokgolo & English (Kriel) \\
\hline $\operatorname{tar}$ & $>$ & tiri for sekontiri & Afrikaans (Kriel) \\
\hline traffic & $>$ & therafiki for sephethephethe & English (Kriel) \\
\hline uphold & $>$ & tshegetša for thekga & Tswana (Kriel) \\
\hline urgent & $>$ & potlakega for phakišalakgofiša & not lemmatised \\
\hline weather & $>$ & wetara for boso & English (Kriel) \\
\hline wind & $>$ & waena for tata/nyopa & English (Kriel) \\
\hline ish & $>$ & lakatša for kganyogelalakela & Sesotho (Kriel) \\
\hline
\end{tabular}

Supposedly one of the main purposes of the compilers was to rectify the usage of unnecessary loanwords in the existing bilingual dictionaries (New English-Northern Sotho Dictionary 1967 and Popular Northern Sotho Dictionary 1988). On the contrary, the compilers simply copied, almost word for word, Kriel's mistakes in the New English-Northern Sotho Dictionary. Out of 38 entries identified as unnecessary loanwords, the compilers have copied 25 articles from Kriel's New English-Northern Sotho Dictionary. Furthermore, in their dictionary they have added 13 more of these unnecessary loanwords from English (feila/fail), Afrikaans (laišal oplaai, meta/meet, motlalei/aanklaer), English and Afrikaans (ť̌ea karolo/take part/deelneem), Sesotho (makgethe), Setswana (mathe) and not lemmatised words (sehlanya, ikgalanya, 
tšalana, potlakega). It should be expected from the compilers to have done thorough research on loanwords before compiling their articles. It was unnecessary to include these loanwords for there exist translated words in vernacular Sepedi which correspond to the English equivalents.

This is not meant to discourage the use of loanwords, for they play a major role in the promotion and development of languages, but borrowing should be handled with extra care so that new loanwords are not introduced in addition to already existing ones.

\section{Corresponding words}

Al-Kasimi (1983:59) argues that the bilingual lexicographer is concerned with translation equivalents. This means that, according to Catford (1965:130), a translation equivalent refers to 'a target-language text, or item in a text which changes when and only when a given source language text or item is changed'. Al-Kasimi (1983:60) takes this issue further by stating that in a bilingual dictionary translations of entry words are divided into two types, namely translational equivalents and explanatory/descriptive equivalents. He explains a translational equivalent as a lexical unit, which can be inserted into a sentence in the target language, while an explanatory/descriptive equivalent refers to a lexical unit, which cannot be inserted into a sentence in the target language.

Wiegand (2002:245) suggests that when it comes to language systems one expects correspondence instead of equivalence, for equivalence in translation refers to meaning-bearing units below the level of a sentence, because it deals with the equivalence of various items consisting of several words not forming idiomatic expressions and collocations. In this manner, equivalence should not be reduced to lexical items, for several cases cannot be taken into account when a source language item is equivalent to a non-lexicalised target language item.

The compiler can follow a certain procedure to determine whether the corresponding lexical item s/he chooses is absolute. This means that it should cover the whole range of the lexical meaning of the entry word. As a result, s/he will collect a broad range of typical contexts in the source language in which the entry word occurs. Hereafter s/he will then translate this entry word into the target language. If the prospective corresponding word can fit in each of the examples of the translated word, then it is absolute, otherwise it is partial (Al-Kasimi 1983:65).

In this discussion correspondence instead of equivalence is opted for although the two might also be employed interchangeably. The following examples show up a correspondence problem area in the New Sepedi Dictionary:

$\begin{array}{ll}\text { heartbeat } & >\text { go opa ga pelo instead of go thebetha ga pelo } \\ \text { insanitary } & >\text { se nago bophelo instead of nago le bophelo } \\ \text { interpreter } & >\text { motoloki instead of mohlatholli } \\ \text { spring } & >\text { selemo instead of seruthwana } \\ \text { praise-name } & >\text { leina la sereto instead of leinatheto/sereto } \\ \text { prohibit } & >\text { ganela instead of ganeť̌althibela/šitiša } \\ \text { sister } & >\text { kgaeť̌edi/ngwanabo instead of kgaetšedi (ya monna)/ngwanabo (wa monna) } \\ \text { stallion } & >\text { poo ya tonki/pere instead of tonki/pere ya poo } \\ \text { summer } & >\text { lehlabula instead of selemo } \\ \text { tsetse fly } & >\text { ntšitsetse instead of (mohuta') seboba }\end{array}$


witchdoctor > ngaka instead of ngaka ya (go loya) moloi

yearly $\quad>$ mengwaga ka mengwaga instead of ngwaga ka ngwaga

In this list, a semantic problem of the dictionary is highlighted, with a suggestion of possible solutions regarding the choice of correspondents. Admittedly, the major task of a bilingual dictionary compiler is to find appropriate correspondents in the target language (Sepedi) for the units of the source language (English). This task, according to Jakobson (1959:233), involves a great deal of translation.

It can be assumed that a major problem which confronted Prinsloo and Sathekge was always to find required correspondents in the target language. As a result, they were, in some instances, obliged to create inappropriate correspondents, which do not exist in the target language. For example, stallion is translated as poo ya tonki/pere instead of tonki/pere ya poo. A phrase such as poo ya tonki/pere is not in common use, being rather archaic (if it does exist). This scarcely adds to the user-friendliness of the dictionary which the compilers claim as an attribute.

\section{Coined words}

When examining names, Koopman (1979: 153) argues that they are derived from nouns:

It is convenient to begin a general analysis of the difference between male and female names by examining the various derivational sources, and seeing which structures may be allowed for male names only, which for female, and which for both. This examination should reveal something of the general characteristics of male and female names. After the structural analysis has been completed, some general conclusions about the linguistic characteristics can be drawn.

The following is a selection of newly coined words in the dictionary.

$\begin{array}{ll}\text { dandruff } & >\text { sekelefere instead of lehlono/sekrofolo } \\ \text { enlighten } & >\text { bonišetša instead of bonegela } \\ \text { epidemic } & >\text { twetšisewa instead of leuba } \\ \text { epidermis } & >\text { letlalokagodimo instead of letlalolakagodimo } \\ \text { gutter } & >\text { kataralkathara instead of khathara } \\ \text { melon } & >\text { sepanspeke instead of melone }\end{array}$

These coinages are unnecessary as there are already existing translations and spellings for these words (cf., for example, dandruff, epidermis and epidemic, in Northern Sotho Terminology and Orthography No 4 of 1988). This merely causes confusion for users because they are confronted not only with new translations for words, but also with new spellings of words for which accepted translations and spellings are already available.

\section{Hyphenated and unhyphenated words}

Northern Sotho Terminology and Orthography No. 4 of 1988 is a decisive document containing the official spelling rules of Standard Sepedi, which has been compiled by the former Sepedi Language Board and is still accepted as an authentic orthographic and spelling document for Sepedi. This is, therefore, a crucial document on the standardisation of written Sepedi to regulate and normalise other written Sepedi texts such as the New Sepedi Dictionary. With regard to the hyphen, Northern Sotho Terminology and Orthography No. 4 of 1988 (p.17) clearly states: 
The hyphen is generally speaking regarded as an additional diacritic, and it is therefore to be avoided as much as possible. Its main use is at the end of the line, when a word is broken. Therefore, compound words should be written each as one word without the hyphen.

Accordingly, Sepedi dictionaries are equally important with regard to language use. It is therefore imperative for the compilers of dictionaries to observe and preserve the prescribed orthographic rules of the language.

The New Sepedi Dictionary gives compound words as follows:

$\begin{array}{ll}\text { low veld } & >\text { naga tlase (written as in English) instead of nagatlase } \\ \text { now } & >\text { gona bjale instead of gonabjale } \\ \text { shale } & >\text { letsopatlapa instead of letlapatsopa (letsopa = clay coming from stone) }\end{array}$

Furthermore the compilers write the following words with a hyphen:

$$
\begin{array}{ll}
\text { wag (tail) } & >\text { tswikinya-mosela instead of tswikinyamosela } \\
\text { deodorant } & >\text { se-bolaya-lefetla instead of sebolayalefetla } \\
\text { vice-chairman } & >\text { motlatša-modulasetulo instead of motlatšamodulasetulo }
\end{array}
$$

In all these examples, the compilers should have observed and employed the rules for hyphenation as prescribed by Northern Sotho Terminology and Orthography No 4 of 1988 .

\section{Repetition of words}

Patton (1994:1) argues:

Repetition as a conduct and as a point of view concerns non-exchangeable and nonsubstitutable singularities. Reflections, echoes, doubles and souls do not belong to the domain of resemblance or equivalence ...

Furthermore, he states that to repeat whatever action is to behave in a certain manner in relation to something unique or singular which has no equal or equivalent. Repetition refers to repeated phrases or parts of words as Kruger (1988:135) confirms:

This occurs when a word or word group is related in exactly the same place as in its preceding line. The following words, indicated in bold for emphasis, are unnecessarily repeated in some articles of the dictionary:

$\begin{array}{ll}\text { deceive } & >\text { radia, fora, thetša, radia } \\ \text { either } & >\text { goba, ye nngwe ya ya bobedi }\end{array}$

This can cause confusion to the inexperienced user. One of the main tasks of the compiler(s) of a dictionary is to guard against ambiguity. As a result, a dictionary should be thoroughly edited, including the editing of the language.

\section{Inconsistencies}

Dictionary articles not conforming to a regular pattern or style can be described as inconsistent. Numerous inconsistencies are found in this dictionary. The following are examples of conjunctive and disjunctive articles appearing in the dictionary: 


\section{Conjunctive words}

flannel graph >

overstock

$>$ kgomaswantšho
$>$ molomosekammutla
$>$ golelaphulo

$\begin{array}{ll}\text { Disjunctive words } \\ \text { wag (tail) } & >\text { tswikinya-mosela } \\ \text { deodorant } & >\text { se-bolaya-lefetla } \\ \text { low veld } & >\text { naga tlase } \\ \text { now } & >\text { gona bjale }\end{array}$

Disjunctive words

The compilers indiscriminately write words conjunctively and disjunctively as can be seen from the above examples; on one hand molomosekammutla (hare-lip) is considered an unhyphenated word, while on the other hand se-bolaya-lefetla (deodorant) is regarded as a hyphenated word. There seems to be no apparent reason for doing this.

The following are examples where the spelling of the same words differs:

$\begin{array}{lllll}\text { prophet } & > & \text { moprofeta } & \text { vs } & \text { moporofeta } \\ \text { Sunday/Tuesday } & > & \text { LaMorena } & \text { vs } & \text { Labobedi } \\ \text { understand } & > & \text { kwišiša } & \text { vs } & \text { kwešiša }\end{array}$

Northern Sotho Terminology and Orthography No 4 of 1988 indicates clearly how, for example, days of the week (Lamorena Sunday, Labobedi Tuesday, Laboraro Wednesday, Labone Thursday, etc.) should be spelled. The compilers use their own spelling for reasons that are not clear.

\section{Conclusion}

Admittedly, very few dictionaries of limited lexical coverage attempt to serve speakers of both languages with some success. It is for this reason that Nida (1961:27) recommends that even though a compiler has much experience in the foreign language, he/she should constantly seek the assistance of a native speaker of that language in order to avoid improper usage, translationisms and other problems that might impede his/her good lexicographic practice. With reference to the discussed dictionary, Sathekge (the mother-tongue informant) should have correctly advised Prinsloo (the non-mother-tongue speaker) on the culture-bound articles, which denote objects peculiar to the culture of the target language, and the scientific and technological terminology, which is absent in Sepedi.

Over and above, the translational equivalents should have been favoured in the New Sepedi Dictionary for it is intended for the speakers of the source language as an aid to produce the target language, Sepedi. A major problem that confronted the compilers was that they could not always find the required correspondents in the target language. Furthermore, the compilers could not successfully employ effective ways as those mentioned by Bull (1964:530): such as to expand or extend the vocabulary by word borrowing, coinage, giving new meaning to existing words, extending the meaning of existing words and compounding new words from existing elements from Sepedi or from Sepedi and other languages (English, Afrikaans, Sesotho and Setswana, in this dictionary).

The solution proposed in this article is based on the assumption that the compilers should observe that terms are consistent with the type of information and language of origin and that the accessibility of all new words should first be tested before they are finally adopted.

Though the good work of the compilers of this dictionary should be acknowledged, it should, however, be recommended that this lexicographic compilation should duly be revisited and be revised. 


\section{REFERENCES}

Al-Kasimi, A.M. 1983. Linguistics and Bilingual Dictionaries. Leiden: E.J. Brill.

Bamgbose, A. 1965. Yoruba Orthography. Ibadan: Ibadan University.

Bull, W.E. 1964. The Use of Vernacular Languages in Education. In: Hymes, D. (ed.). 1964.

Language in Culture and Society. New York: Harper and Row: 523-533.

Catford, J.C. 1965. A Linguistic Theory of Translation: An Essay in Applied Linguistics. London: Oxford University Press.

Haas, M.R. 1967. What Belongs in a Bilingual Dictionary? In: Householder, F.W. \& Saporta, S. (eds.). 1967. Problems in Lexicography. Bloomington: Indiana University: 45-50.

Jakobson, R. 1959. On Linguistic Aspects of Translation. In: Brower, R.A. (ed.). 1959. On Translation. Cambridge, Mass.: Harvard University Press: 232-239.

Kaye, J. \& Nykiel, B. 1979. Loan Words and Abstract Phonotactic Constraints. Canadian Journal of Linguistics, 24: 71-93.

Koopman, A. 1979. Male and Female Names in Zulu. African Studies, 38.

Kriel, T.J. 1985. New English-Northern Sotho Dictionary. Johannesburg: Educum.

Kriel, T.J. 1988. Popular Northern Sotho Dictionary. Third Edition. Pretoria: J.L. van Schaik.

Liberman, A. 1980. Orthography and Phonemics in Present-Day Russian. In: Kavanagh, J.F. \& Venezky, R.L. (eds.). 1980. Orthography, Reading and Dyslexia. Baltimore: University Park Press: 51-55.

Malkiel, Y. 1967. A Typological Classification of Dictionaries on the Basis of Distinctive Features. In: Householder, F.W. and Saporta, S. (eds.). 1967. Problems in Lexicography. Bloomington: Indiana University: 3-24.

Martin, S.E. 1967. Selection and Presentation of Ready Equivalents in a Translation Dictionary. In: Householder, F.W. and Saporta, S. (eds.). 1967. Problems in Lexicography. Bloomington: Indiana University: 153-159.

Mountford, J. 2003. An Insight into English Spelling. London: Hodder \& Stoughton Educational.

Nida, E.A. 1961. Bible Translation. London: United Bible Societies.

Patton, P. 1994. Difference and Repetition. New York: Columbia University Press.

Picard, M. \& Nicol, J. 1982. Loanwords and Concrete Phonology. Indiana University Linguistics Club.

Pinsent, P. 1989. Spotlight on Spelling. Bicester: A.B. Academic Publishers.

Prinsloo, D.J. \& Sathekge, B.P. 1996. New Sepedi Dictionary. Pietermaritzburg: Shuter and Shooter.

Smit, M. 2002. The Systematic Development of Wiegand's Metalexicography as Demonstrated in Kleine Schriften. Lexikos, 12: 290-310.

Wiegand, H.E. 2002. Equivalence in Bilingual Lexicography: Criticism and Suggestions. Lexikos, 12: 239-255.

Wolff, H. 1954. Nigeria Orthography. Zaria: The Northern Region Adult Education Office.

Wolff, H. 1988. Northern Sotho Terminology and Orthography No 4. Pretoria: Government Printer. 


\title{
ABOUT THE AUTHOR
}

\author{
MJ Mojalefa \\ Department of African Languages \\ University of Pretoria \\ PRETORIA \\ Republic of South Africa \\ Email: jerry.mojalefa@up.ac.za
}

